\title{
GlobWat - a global water balance model to assess water use in irrigated agriculture
}

\author{
J. Hoogeveen ${ }^{1,3}$, J.-M. Faurès ${ }^{1}$, L. Peiser ${ }^{1}$, J. Burke ${ }^{2}$, and N. van de Giesen ${ }^{3}$ \\ ${ }^{1}$ Food and Agriculture Organization of the United Nations, Rome, Italy \\ ${ }^{2}$ World Bank, Washington, D.C., USA \\ ${ }^{3}$ Delft University of Technology, Delft, the Netherlands \\ Correspondence to: J. Hoogeveen (jippe.hoogeveen@fao.org)
}

Received: 1 December 2014 - Published in Hydrol. Earth Syst. Sci. Discuss.: 20 January 2015

Accepted: 9 August 2015 - Published: 10 September 2015

\begin{abstract}
GlobWat is a freely distributed, global soil water balance model that is used by the Food and Agriculture Organization (FAO) to assess water use in irrigated agriculture, the main factor behind scarcity of freshwater in an increasing number of regions. The model is based on spatially distributed high-resolution data sets that are consistent at global level and calibrated against values for internal renewable water resources, as published in AQUASTAT, the FAO's global information system on water and agriculture. Validation of the model is done against mean annual river basin outflows.

The water balance is calculated in two steps: first a "vertical" water balance is calculated that includes evaporation from in situ rainfall ("green" water) and incremental evaporation from irrigated crops. In a second stage, a "horizontal" water balance is calculated to determine discharges from river (sub-)basins, taking into account incremental evaporation from irrigation, open water and wetlands ("blue" water). The paper describes the methodology, input and output data, calibration and validation of the model. The model results are finally compared with other global water balance models to assess levels of accuracy and validity.
\end{abstract}

\section{Introduction}

Modelling of the world's hydrological cycle is important to assess, among others, water resources availability and the sustainability of their use, the impact of climate change, and the influence on global food production (Wood et al., 2011). With regard to global food production, one of the major questions on the future of irrigated agriculture is whether there will be sufficient freshwater to satisfy the growing needs of agricultural and non-agricultural users. Agriculture accounts for about $70 \%$ of the freshwater withdrawals in the world (FAO, 2013), while consumptive use of water in agriculture (water that is evaporated on irrigated fields) accounts for about $90 \%$ of all of the water that is evaporated as a result of human intervention. Irrigated agriculture is therefore the main component of water demand and a driver of scarcity of freshwater in an increasing number of regions.

AQUASTAT (FAO, 2013), the Food and Agriculture Organization's (FAO's) information system on water and agriculture, collects its information mainly from country statistics and grey literature. As part of the AQUASTAT programme, FAO distributes and contributes to the maintenance and development of the Global Map of Irrigation Areas (Siebert et al., 2007, 2010, 2013), which is compatible with AQUASTAT country figures for areas equipped for irrigation. Assessing the impact of irrigation on water scarcity requires information about the geographical distribution of water use 
in irrigation. The Global Map of Irrigation Areas provides information about the distribution of land under irrigation, but data collection through AQUASTAT country surveys has shown that country statistics for agricultural water withdrawals are not always available, and when they exist, they are often unreliable. In most cases they are rough estimates based on water use per unit area of land equipped for irrigation.

Actual water use in annual water balances is changing over time as cropping patterns and cropping intensities shift and change, sometimes in response to available water resources. Therefore a consistent global picture of water withdrawals and consumptive use in irrigated agriculture cannot be obtained without some reference to modelled estimates. Simulation of water use in irrigated agriculture at global scale at the highest available resolution would therefore address a gap in hydrological understanding under contemporary land and water use patterns.

A number of global models exist that simulate water use in agriculture. WaterGAP (Döll and Fiedler, 2008; Hunger and Döll, 2008; Alcamo et al., 2007), WBMplus (Wisser et al., 2010), GEPIC (Liu, 2009; Liu and Yang, 2010), LPJmL (Biemans, 2012; Rost et al., 2008) and PCR-GLOBWB (Wada et al., 2014) are all global hydrological models that have been used to calculate water use by irrigated agriculture. Most of these models are sophisticated hydrological models that are used for detailed water balance analyses in which consumptive water use in agriculture is only one of the components of the water balance rather than the main focus of analysis. Almost all of them are developed at a spatial disaggregation (30 arcmin or coarser) which is not directly comparable with the heterogeneity and spatial variability of irrigation as captured in the FAO's high-resolution ( 5 arcmin) Global Map of Irrigation Areas or in other global agriculture land use data such as that available through FAO and IIASA's Global Agro-Ecological Zones portal (FAO/IIASA, 2012).

To overcome this incompatibility between global hydrological models and the Global Map of Irrigation Areas, Siebert and Döll (2008, 2010) developed the Global Crop Water Model (GCWM) to calculate irrigated crop water requirements on a grid resolution of 5 arcmin by using the MIRCA2000 data set (Portmann et al., 2008). However, contrary to the earlier mentioned models, the GCWM does not simulate the influence of incremental crop evapotranspiration on the hydrological cycle to the extent that model results can be calibrated or validated on river discharges.

Therefore, in order to be able to estimate current and future water use in agriculture objectively and the consequent impact on river basin mean annual flow, a global water balance model, GlobWat, was developed. The defining feature of the model is that it is based on a set of spatially differentiated data sets at $5 \mathrm{arcmin}$ resolution that are consistent at global level, and that model outputs are validated against actual basin outflows.
The model is designed to complement other FAO data sets and models as used for AQUASTAT (FAO, 2013), Global Agro-Ecological Zones (FAO/IIASA, 2012) and Global Perspective Studies (FAO, 2006, 2011a).

\section{Methodology}

Precipitation provides part of the water crops' need to satisfy their transpiration requirements. The soil stores part of the precipitation water, which is later evaporated or transpired by plants. In humid climates, the water stored by the soil is sufficient to ensure satisfactory growth in rainfed agriculture. Instead, in climates with extended dry periods, irrigation is necessary to compensate for the evaporation deficit due to insufficient precipitation. The purpose of the modelling exercise is to estimate net irrigation water requirements on irrigated land. In terms of a hydrological balance, this is incremental evaporation due to the import of water onto land. Net irrigation water requirements in irrigation are calculated as the volume of water needed to compensate for the deficit between potential crop evaporation and effective precipitation over the growing period of the crop. This requirement varies considerably with climatic conditions, seasons, crops and soil types. Following Savenije (2004), the model description uses the term evaporation $(E)$ to describe evaporative processes originating from soil evaporation, transpiration and interception. In agro-hydrology these processes are often referred to as evapotranspiration (ET).

GlobWat has spatially distributed input and output layers consisting of monthly precipitation, number of wet days per month, coefficient of variation of precipitation, monthly reference evaporation, maximum soil moisture storage capacity, maximum groundwater recharge flux, irrigated areas, land use, and areas of open water and wetlands. All these input layers are based on freely available spatial data sets with a resolution of 10 arcmin for the climate data sets and 5 arcmin for all the terrain and land data sets (details and references of the data sets are given in Table 3 ).

The global water balance is calculated in two steps. First a one-dimensional "vertical" water balance is solved (in daily time steps, on a spatial grid layer with a resolution of 5 arcmin) to calculate rainfed evaporation (including rainfed evaporation over open water and wetlands) and evaporation from irrigated areas. In a second step, a "horizontal" water balance for surface water is calculated (in monthly time steps, on the basis of a spatial layer with catchments) to correct for the incremental evaporation from open water and wetlands and to calculate river discharges from (subbasins taking into consideration the net water demand for irrigation. The monthly time step for the horizontal balance is justified, on the basis of the hydrological lag between daily rainfall events and outflows generated from runoff and effluent groundwater discharge, in combination with the size of the river basins considered. The use of vertical and horizon- 
tal water balances helps to clarify discussions on "green" and "blue" water (Falkenmark and Rockström, 2004), as well as on water footprints (Hoekstra and Chapagain, 2007), since it can distinguish between evaporation attributable to land management (evaporation from in situ rainfall) and evaporation attributable to water management (evaporation resulting from the lateral import of water). The significance of open water and wetlands as evaporative "sinks" is also made explicit. A schematic representation of these two calculation steps is given in Fig. 1.

Under long-term, stationary conditions (therefore ignoring changes in hydrological storage), the model is based on two simple equations. For the vertical water balance,

$P+E_{\text {incr-irr }}=E_{\text {rain }}+E_{\text {incr-irr }}+R_{\mathrm{O}}+R$,

and for the horizontal (surface) water balance,

$Q_{\text {out }}=Q_{\text {in }}+R_{\mathrm{O}}+R-E_{\text {incr-irr }}-E_{\text {incr-OW }}-E_{\text {incr-wetl }}$,

where $P$ is precipitation $\left(\mathrm{L}^{3} \mathrm{~T}^{-1}\right), E_{\text {rain }}$ is rainfed evaporation $\left(\mathrm{L}^{3} \mathrm{~T}^{-1}\right), Q_{\text {in }}$ is inflow $\left(\mathrm{L}^{3} \mathrm{~T}^{-1}\right), R_{\mathrm{O}}$ is (sub-)surface runoff $\left(\mathrm{L}^{3} \mathrm{~T}^{-1}\right), R$ is groundwater recharge (in step 1)/baseflow (in step 2) $\left(\mathrm{L}^{3} \mathrm{~T}^{-1}\right), E_{\text {incr-irr }}$ is incremental evaporation from irrigation $\left(\mathrm{L}^{3} \mathrm{~T}^{-1}\right), E_{\text {incr-OW }}$ is incremental evaporation over open water $\left(\mathrm{L}^{3} \mathrm{~T}^{-1}\right), E_{\text {incr-wetl }}$ is incremental evaporation over wetlands $\left(\mathrm{L}^{3} \mathrm{~T}^{-1}\right)$ and $Q_{\text {out }}$ is outflow $\left(\mathrm{L}^{3} \mathrm{~T}^{-12}\right)$, where $L$ is length and $T$ is time.

The detailed calculations procedure for the respective model components is explained below.

\section{Soil water balance}

The soil water balance model is similar to the Thornwaite and Mather procedure (Steenhuis and Van der Moolen, 1986) adapted for daily time steps. The basic soil water balance equation for this model is as follows:

$P=E_{\text {rain }}+R+R_{\mathrm{O}}+\Delta S / \Delta t$,

with $\quad P=$ precipitation $\quad\left(\mathrm{mm} \mathrm{day}^{-1}\right), \quad E_{\text {rain }}=$ rainfalldependent evaporation $\left(\mathrm{mm} \mathrm{day}^{-1}\right), \quad R=$ groundwater recharge $\left(\mathrm{mm} \mathrm{day}^{-1}\right), \quad R_{\mathrm{O}}=($ sub-)surface runoff $\left(\mathrm{mm} \mathrm{day}^{-1}\right), \Delta S=$ changes in soil moisture storage (mm) and $\Delta t=$ time step (day).

The computation of water balance is carried out on a spatial resolution of 5 arcmin grid cells and in daily time steps taking account of spatial variations in rainfall, evaporative power of the atmosphere and soil properties.

\section{Precipitation}

Daily precipitation is generated from monthly figures by using a mixed Bernoulli gamma distribution function (Wilks and Wilby, 1999). First the number of wet days is randomly distributed over the month by using a Bernoulli distribution, and then the amount of monthly precipitation is randomly distributed over the wet days by using a gamma distribution with parameters derived from the data set with coefficients of variation of precipitation.

Usually, precipitation generators use Markov chains to generate precipitation events (Schoof and Pryor, 2008). However, the data sets used do not include information to parameterise these Markov chains. To take into consideration that the chance of rainfall after a wet day is higher than the chance of rainfall after a dry day, the following simple adjustment was made:

$P_{\text {wet wet }}=(1+$ corr $) \times P_{\text {wet mean }}$

and

$P_{\text {wet dry }}=P_{\text {wet mean }} \times\left(1-P_{\text {wet wet }}\right) /\left(1-P_{\text {wet mean }}\right)$,

with $P_{\text {wet wet }}$ is the probability of a wet day after a wet day, $P_{\text {wet dry }}$ is the probability of a wet day after a dry day, and $P_{\text {wet mean }}$ is the average probability of a wet day calculated as

$P_{\text {wet mean }}=$ wet days $/$ days of the month.

corr $=$ correction coefficient is calculated as

corr $=0.5 \times($ days of the month - wet days $) /$ days of the month.

Applying this adjustment, the chance of a wet day after a wet day is almost 1.5 times as high when the number of wet days approaches 0 , while the chance of a wet day after a wet day approaches the average chance of a wet day if the number of wet days is high.

The spatial distribution of all climate data is determined by the CRU CL 2.0 data set (New et al., 2002). This data set has been chosen to obtain maximum consistency between precipitation and reference evaporation, and because it describes average climatic conditions, which are comparable to the data available in AQUASTAT.

\section{Rainfall-dependent evaporation}

Rainfall-dependent evaporation $\left(E_{\text {rain }}\right)$ is assumed to be equal to the maximum evaporation of a land use or vegetation type when evaporation is not hampered by water shortage. Maximum evaporation is calculated by multiplying reference evaporation by a crop or land use factor (Allen et al., 1998). In dry periods, when the available soil moisture is reduced below a certain level, lack of water reduces evaporation to an extent proportional to the available soil moisture. 
Step 1:

'Vertical' water balance (calculated per grid cell)
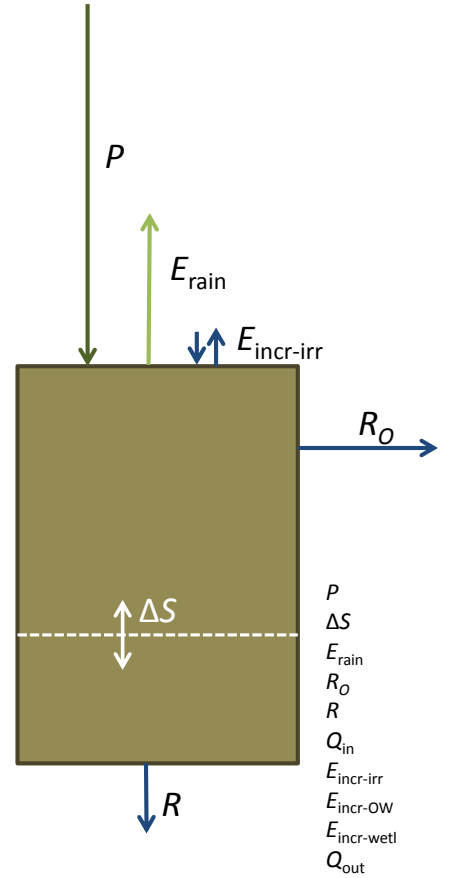

Step 2:

'Horizontal' water balance

(calculated per catchment)

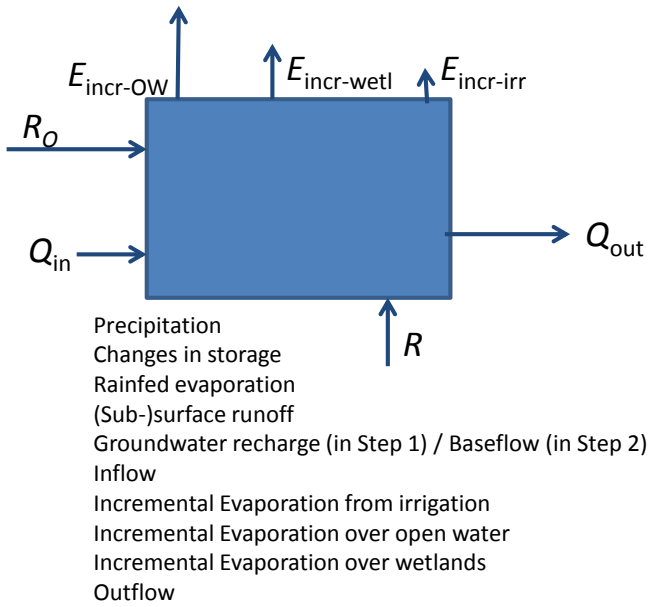

Figure 1. Schematic representation of modelling steps.

Table 1. Vegetation types derived from FAO's Global Agricultural Systems Map.

\begin{tabular}{ll}
\hline Vegetation class & $K c$ factor \\
\hline Rainfed agriculture: dry tropics & 0.9 \\
Rainfed agriculture: humid tropics & 1 \\
Rainfed agriculture: highlands & 0.9 \\
Rainfed agriculture: subtropics & 1 \\
Rainfed agriculture: temperate & 1 \\
Rangelands: subtropics & 0.8 \\
Rangelands: temperate & 0.9 \\
Rangelands: boreal & 0.8 \\
Forest & 1.1 \\
Desert & 0.7 \\
Other & 1 \\
\hline
\end{tabular}

In equations:

$$
\begin{aligned}
& E_{\text {rain }}(t)=K_{\mathrm{c}} \times E_{\mathrm{o}}(t) \text { for } S_{\mathrm{max}} \geq S(t-1) \geq S_{\mathrm{eav}} \\
& E_{\text {rain }}(t)=K_{\mathrm{c}} \times E_{\mathrm{o}}(t) \times S(t-1) /\left(S_{\text {eav }}\right) \text { for } S(t-1)<S_{\text {eav }} \\
& S_{\text {eav }}=0.5 \times S_{\text {max }} \\
& S_{\text {max }}=\mathrm{Rt}_{\mathrm{d}} \times \mathrm{SC}_{\max }
\end{aligned}
$$

with $t$ the time step indicator, $E_{\text {rain }}(t)$ the rainfed evaporation on $t\left(\mathrm{~mm} \mathrm{day}^{-1}\right), E_{\mathrm{0}}(t)$ the reference evaporation on $t$ $\left(\mathrm{mm} \mathrm{day}^{-1}\right), K_{\mathrm{c}}$ the crop or land use factor $(-), S(t-1)$ the available soil moisture on $t-1(\mathrm{~mm}), S_{\max }$ the maximum soil moisture storage $(\mathrm{mm}), S_{\text {eav }}$ the easily available soil moisture (mm), $\mathrm{Rt}_{\mathrm{d}}$ the effective root depth (m), and $\mathrm{SC}_{\max }$ the maximum soil moisture storage capacity $\left(\mathrm{mm} \mathrm{m}^{-1}\right)$.

The crop or land use factor $K_{\mathrm{c}}$ is not constant over the year. It varies during the growing season, depending on the growing stage. However, for rainfed conditions, differentiated $K_{\mathrm{c}}$ factors were not applied, since no distinction was made between the different crops and their cropping calendars. The $K_{\mathrm{c}}$ factors used were attributed to the Global Agricultural Systems Map (FAO, 2011b) according to Table 1.

As can be seen from the equations above, the easily available soil moisture $\left(S_{\text {eav }}\right)$ is defined as half the maximum soil moisture storage $\left(S_{\max }\right)$. In reality, easily available moisture depends on the type of plant, its growing stage and its soil type, and it varies from about 40 to $60 \%$ of the maximum soil moisture storage capacity $\left(\mathrm{SC}_{\max }\right)$ (Raes et al., 2012). For a global model, $50 \%$ can be considered a reasonable approximation.

The spatial distribution of the maximum soil moisture storage capacity $\left(\mathrm{SC}_{\max }\right)$ was derived from the Harmonised World Soil Database (FAO, 2012).

The effective root depth of vegetation is the part of the root zone from which the plant extracts the majority of the water it needs, and therefore it depends both on soil and plant characteristics as well as the amount of water available. There 
are different ways to estimate the effective root depth, i.e. half the maximum root depth (Evans et al., 1996) or the soil depth in which $90 \%$ of the weight of the roots is found (Allen et al., 1998; FAO, 1978). However, for a global model, such information is not available and therefore an initial effective rooting depth of $60 \mathrm{~cm}$ is assumed. Since the results of model computation are very sensitive to effective rooting depth and to soil moisture storage capacity $\left(\mathrm{SC}_{\max }\right)$, both parameters were used to calibrate the model.

\section{Groundwater recharge, actual available soil moisture and (sub-)surface runoff}

Groundwater recharge is assumed to occur only above a threshold level when there is enough water available in the soil to percolate downward in the model. The recharge rate depends on a maximum possible groundwater recharge flux, which is derived from the Groundwater Resources of the World Map provided by the World-wide Hydrogeological Mapping and Assessment Programme (WHYMAP) (BGR and UNESCO, 2008), and is assumed to be proportional to the available soil moisture. The recharge component is assumed to contribute to the shallow groundwater circulation that appears as effluent seepage in the annually renewable water resource account of the respective basins. Given that all groundwater heads are generated by tectonic uplift and fluvial erosion, all groundwater flows in the model are assumed to enter the annual river basin balance and not enter permanent groundwater storage.

In equations:

$$
\begin{aligned}
R(t)= & R_{\max } \times\left(S(t-1)-S_{\text {eav }}\right) /\left(S_{\mathrm{max}}-S_{\mathrm{eav}}\right) \\
& \text { for } S_{\mathrm{max}} \geq S(t-1) \geq S_{\mathrm{eav}},
\end{aligned}
$$

$R(t)=0$ for $S(t-1)<S_{\text {eav }}$,

with $R(t)$ the recharge flux on $t\left(\mathrm{~mm} \mathrm{day}^{-1}\right)$ and $R_{\max }$ the maximum groundwater recharge flux $\left(\mathrm{mm} \mathrm{day}^{-1}\right)$.

The available soil moisture is calculated per day by adding ingoing and outgoing fluxes to the available soil moisture of the day before. Runoff occurs when the balance of the ingoing and outgoing fluxes exceeds the maximum soil moisture storage capacity.

In equations:

$$
\begin{aligned}
& B(t)=S(t-1)+\left(P(t)-E_{\mathrm{rain}}(t)-R_{\mathrm{O}}(t)\right) \cdot \Delta t \\
& \text { If } B(t)<S_{\max }, \text { then } \\
& S(t)=B(t), \\
& R_{\mathrm{O}}(t)=0 .
\end{aligned}
$$

If $B(t) \geq S_{\max }$, then
$S(t)=S_{\max }$

$R_{\mathrm{O}}(t)=\left(B(t)-S_{\max }\right) / \Delta t$,

with $B(t)$ the balance on $t(\mathrm{~mm}), R_{\mathrm{O}}(t)$ the (sub-)surface runoff on $t\left(\mathrm{~mm} \mathrm{day}^{-1}\right)$ and $S(t)$ the available soil moisture on $t(\mathrm{~mm})$.

\section{Evaporation for crops under irrigation}

Evaporation for crops under irrigation is calculated by multiplying reference evaporation by a crop and growing stage specific factor according to the FAO Penman-Monteith method (Allen et al., 1998). It is assumed that there is always enough water available to ensure that crops under irrigation never suffer water stress.

The evaporation of a crop under irrigation $\left(E_{\mathrm{c}}\right)$ is calculated as follows:

$E_{\mathrm{c}}(t)=K_{\mathrm{c}} \times E_{\mathrm{o}}(t)$,

with $E_{\mathrm{c}}(t)$ crop evaporation under irrigation on $t$ $\left(\mathrm{mm}\right.$ day $\left.^{-1}\right), E_{\mathrm{o}}(t)$ reference evaporation on $t\left(\mathrm{~mm} \mathrm{day}^{-1}\right)$ and $K_{\mathrm{c}}$ the rop or land use factor (-).

Crop coefficients $\left(K_{\mathrm{c}}\right)$ have been derived for four different growing stages: the initial phase (just after sowing), the development phase, the mid-phase and the late phase (when the crop is ripening to be harvested). In general, these coefficients are low during the initial phase, after which they increase during the development phase to high values in the mid-phase, and again decrease in the late phase. It is assumed that the initial phase, the development phase and the late phase each take 1 month for each crop, while the duration of the mid-phase varies according to the type of crop. For example, the growing season for wheat in Morocco starts in October and ends in April, as follows: initial phase: October $\left(K_{\mathrm{c}}=0.4\right)$; development phase: November $\left(K_{\mathrm{c}}=0.8\right)$; midphase: December-March $\left(K_{\mathrm{c}}=1.15\right)$; and late phase: April $\left(K_{\mathrm{c}}=0.3\right)$.

Evaporation requirements of crops in irrigated agriculture are calculated by converting data of irrigated area by crop (at the national level) into a cropping calendar with monthly occupation rates of the land equipped for irrigation. Cropping calendars have been developed by AQUASTAT (http://www. fao.org/nr/water/aquastat/water_useagr/index $2 . s t m)$ for each of the countries or country groups of the study (except for China, India and the United States, which were divided into several zones of homogenous cropping patterns). Table 2 presents the irrigation cropping calendar for Morocco, derived from AQUASTAT data for the year 2004.

The rate of evaporation coming from the irrigated area per month and per grid cell is calculated by multiplying the area equipped for irrigation as derived from the Global Map of Irrigation Areas (Siebert et al., 2007) by cropping intensity and crop evaporation for each crop: 
$E_{\text {c-total }}(t)=I_{\mathrm{A}} \times \Sigma_{\mathrm{c}}\left(C_{\mathrm{Ic}} \times E_{\mathrm{c}}(t)\right)$,

with $E_{\mathrm{c} \text {-total }}(t)$ total evaporation for all crops under irrigation on $t$ in $\mathrm{mm} \mathrm{day}^{-1}, I_{\mathrm{A}}$ the area equipped for irrigation as percentage of cell area for the given grid cell, $c$ crop under irrigation, $\Sigma_{\mathrm{c}}$ the sum over the different crops, $C_{\text {Ic }}$ the cropping intensity for crop $c$ and $E_{\mathrm{c}}(t)$ the crop evaporation on $t$ in $\mathrm{mm} \mathrm{day}^{-1}$, varying for each crop and each growth stage.

The difference between the calculated evaporation of the irrigated area, $E_{\mathrm{c}}$, and the evaporation provided by rainfall, $E_{\text {rain }}$, is equal to the incremental evaporation due to irrigation, which equals the net irrigation water requirement:

$E_{\text {incr-irr }}(t)=E_{\text {c-total }}(t)-E_{\text {rain }}(t)$,

with $E_{\text {incr-irr }}(t)$ the incremental evaporation due to irrigation on $t\left(\mathrm{~mm} \mathrm{day}^{-1}\right)$.

\section{Evaporation from open water and swamps}

A special correction is applied for grid cells existing of open water or swamps. In these areas, the actual evaporation depends on heat storage in lakes and reservoirs, which is related to the depth of the water bodies, and, in the case of swamps and wetlands, the vegetation. In the model, evaporation from open water is computed in a simplified manner as follows:

$E_{\text {ow }}(t)=K_{\text {ow }} \times E_{\mathrm{o}}(t)$

and

$B(t)=\left(P(t)-E_{\mathrm{ow}}(t)\right) \cdot \Delta t$,

with $E_{\mathrm{ow}}(t)$ actual evaporation over open water on $t$ (mm day ${ }^{-1}$ ), $K_{\text {ow }}$ the open water coefficient $(-)$ and $B(t)$ the open water balance on $t(\mathrm{~mm})$.

If $B(t)<0$, then

$R_{\mathrm{O}}(t)=0$,

$E_{\text {rain }}(t)=P(t)$,

$E_{\text {incr-ow }}(t)=(-1 \times B(t)) / \Delta t$.

If $B(t) \geq 0$, then

$R_{\mathrm{O}}(t)=B(t) / \Delta t$,

$E_{\text {rain }}(t)=E_{\text {ow }}(t) / \Delta t$,

$E_{\text {incr-ow }}(t)=0$,

with $E_{\text {incr-ow }}(t)$ the incremental evaporation over open water on $t\left(\mathrm{~mm} \mathrm{day}^{-1}\right)$.

Evaporation over swamps and wetlands is calculated separately, but in the same way as evaporation over open water. For this study, open water evaporation and evaporation over swamps and wetlands is assumed to be $10 \%$ higher than reference evaporation $\left(K_{\mathrm{ow}}=1.1\right)$.
The spatial distribution of open water and wetlands was derived from the global map of lakes and wetlands (Lehner and Döll, 2004).

It was decided to make a distinction between the rainfalldependent evaporation over open water and incremental evaporation over open water, to make it possible to distinguish between evaporation of water that is available from the "vertical" water balance (the rainfall minus evaporation) and the water that has to come from outside the spatial domain of calculation (the incremental evaporation).

\section{River basin discharges}

To calculate discharges from river basins and sub-basins, a global map of river basins was used which was developed in the framework of the FAO's study "The state of the world's land and water resources for food and agriculture - managing systems at risk" (FAO, 2011b). For this study, major river basins and their sub-basins were delineated from the HydroSHEDS database. Sub-basins were named and assigned a flow direction, indicating the sub-basin directly downstream of each sub-basin. Aggregated water balances were calculated on a monthly time step by subtracting all evaporation occurring over the sub-basin from the sum of the total precipitation over the sub-basin and the inflow from upstream basins (Eq. 30).

$B_{\mathrm{sb}}(t)=Q_{\mathrm{in}}(t)+\sum P(t)-\sum E(t)$

with $B_{\mathrm{sb}}$ the water balance of aggregated grid cells in a subbasin $\left(\mathrm{m}^{3}\right.$ month $\left.^{-1}\right), t$ the time step indicator, $Q_{\text {in }}$ the incoming flow in the sub-basin calculated as the sum of the outflow from all upstream sub-basins $\left(\mathrm{m}^{3}\right.$ month $\left.^{-1}\right), \sum P$ the precipitation summed over all grid cells in the sub-basin $\left(\mathrm{m}^{3}\right.$ month $\left.^{-1}\right)$ and $\sum E$ the total evaporation summed over all grid cells in the sub-basin $\left(\mathrm{m}^{3} \mathrm{month}^{-1}\right)$.

There is a lag between the time water enters a sub-basin and the time it gets out, and some of the inflow is trapped in storage in the sub-basin. To take the time lag and storage effect into account, a simple linear reservoir model (De Zeeuw, 1973 ) is used to calculate monthly values for river discharges and the amount of water stored per sub-basin:

$S_{\mathrm{sb}}(t)=S_{\mathrm{sb}}(t-1)+\left(B_{\mathrm{sb}}(t)-Q_{\text {out }}(t-1)\right) \cdot \Delta t$

and

$Q_{\text {out }}(t)=S_{\mathrm{sb}}(t) \times F$

with $S_{\mathrm{sb}}$ the river sub-basin storage $\left(\mathrm{m}^{3}\right), \Delta t$ the time step (month), $Q_{\text {out }}$ the outflow from the sub-basin $\left(\mathrm{m}^{3}\right.$ month $\left.^{-1}\right)$ and $F$ the response factor (1/month).

The response factor $F$ in Eq. (32) depends on the size and the characteristics of the sub-basin. It can be defined as the one over the retention time of the water in the basin in months. For small, quickly reacting sub-basins, the monthly 
Table 2. Cropping calendar in irrigation for Morocco for the year 2004.

\begin{tabular}{|c|c|c|c|c|c|c|c|c|c|c|c|c|c|c|}
\hline \multirow{2}{*}{$\begin{array}{l}\text { Crop under } \\
\text { irrigation }\end{array}$} & \multirow{2}{*}{\multicolumn{2}{|c|}{$\begin{array}{l}\text { Irrigated } \\
\text { area } \\
(1000 \mathrm{ha})\end{array}$}} & \multicolumn{12}{|c|}{ Crop area as share (per cent) of the total area actually irrigated by month } \\
\hline & & & $\mathrm{J}$ & $\mathrm{F}$ & M & A & M & $\mathrm{J}$ & $\mathrm{J}$ & $\mathrm{A}$ & $\mathrm{S}$ & $\mathrm{O}$ & $\mathrm{N}$ & $\mathrm{D}$ \\
\hline Wheat & 355 & & $24 \%$ & $24 \%$ & $24 \%$ & $24 \%$ & & & & & & $24 \%$ & $24 \%$ & $24 \%$ \\
\hline Rice & 8 & & & & $1 \%$ & $1 \%$ & $1 \%$ & $1 \%$ & $1 \%$ & & & & & \\
\hline Maize & 60 & & & & & $4 \%$ & $4 \%$ & $4 \%$ & $4 \%$ & $4 \%$ & & & & \\
\hline Barley & 95 & & $6 \%$ & $6 \%$ & $6 \%$ & & & & & & & $6 \%$ & $6 \%$ & $6 \%$ \\
\hline Potatoes & 31 & & & & & & & & & & & & & \\
\hline - First season & & 20 & $1 \%$ & $1 \%$ & $1 \%$ & $1 \%$ & & & & & & & & $1 \%$ \\
\hline - Second season & & 10 & & & & & $1 \%$ & $1 \%$ & $1 \%$ & $1 \%$ & $1 \%$ & & & \\
\hline Sugar beet & 75 & & & & $5 \%$ & $5 \%$ & $5 \%$ & $5 \%$ & $5 \%$ & $5 \%$ & & & & \\
\hline Sugar cane & 23 & & $2 \%$ & $2 \%$ & $2 \%$ & $2 \%$ & $2 \%$ & $2 \%$ & $2 \%$ & $2 \%$ & $2 \%$ & $2 \%$ & $2 \%$ & $2 \%$ \\
\hline Pulses & 47 & & & & & & & & & & & & & \\
\hline - First season & & 21 & $1 \%$ & $1 \%$ & & & & & & & & $1 \%$ & $1 \%$ & $1 \%$ \\
\hline - Second season & & 26 & & & $2 \%$ & $2 \%$ & $2 \%$ & $2 \%$ & $2 \%$ & & & & & \\
\hline Vegetables & 205 & & & & & & & & & & & & & \\
\hline - First season & & 146 & $10 \%$ & $10 \%$ & $10 \%$ & $10 \%$ & & & & & & & & \\
\hline - Second season & & 49 & & & & & $3 \%$ & $3 \%$ & $3 \%$ & $3 \%$ & & & & \\
\hline - Third season & & 10 & & & & & & & & & $1 \%$ & $1 \%$ & $1 \%$ & $1 \%$ \\
\hline Citrus & 78 & & $5 \%$ & $5 \%$ & $5 \%$ & $5 \%$ & $5 \%$ & $5 \%$ & $5 \%$ & $5 \%$ & $5 \%$ & $5 \%$ & $5 \%$ & $5 \%$ \\
\hline Fruits & 131 & & $9 \%$ & $9 \%$ & $9 \%$ & $9 \%$ & $9 \%$ & $9 \%$ & $9 \%$ & $9 \%$ & $9 \%$ & $9 \%$ & $9 \%$ & $9 \%$ \\
\hline Oil crops & 187 & & $13 \%$ & $13 \%$ & $13 \%$ & $13 \%$ & $13 \%$ & $13 \%$ & $13 \%$ & $13 \%$ & $13 \%$ & $13 \%$ & $13 \%$ & $13 \%$ \\
\hline Sunflower & 14 & & & & $1 \%$ & $1 \%$ & $1 \%$ & $1 \%$ & $1 \%$ & & & & & \\
\hline Cotton & 8 & & & & $1 \%$ & $1 \%$ & $1 \%$ & $1 \%$ & $1 \%$ & $1 \%$ & $1 \%$ & & & \\
\hline Fodder (annual) & 133 & & $9 \%$ & $9 \%$ & $9 \%$ & & & & & & & $9 \%$ & $9 \%$ & $9 \%$ \\
\hline Fodder (perennial) & 15 & & $1 \%$ & $1 \%$ & $1 \%$ & $1 \%$ & $1 \%$ & $1 \%$ & $1 \%$ & $1 \%$ & $1 \%$ & $1 \%$ & $1 \%$ & $1 \%$ \\
\hline Sum over all crops & 1465 & & $81 \%$ & $81 \%$ & $93 \%$ & $77 \%$ & $46 \%$ & $46 \%$ & $46 \%$ & $39 \%$ & $31 \%$ & $71 \%$ & $71 \%$ & $72 \%$ \\
\hline Actually irrigated & 1485 & & & & & & & & & & & & & \\
\hline $\begin{array}{l}\text { Equipped for } \\
\text { irrigation }\end{array}$ & 1485 & & & & & & & & & & & & & \\
\hline $\begin{array}{l}\text { Total cropping } \\
\text { intensity }\end{array}$ & $99 \%$ & & & & & & & & & & & & & \\
\hline
\end{tabular}

outflow can be equal to the monthly inflow and $F$ will be 1 . Large sub-basins or sub-basins with high storage capacity have high retention times and therefore low values for the response factor $F$. For all sub-basins in this study a response factor $F$ of 0.3 was assumed. No differentiation was made between different carry-over factors since analysing monthly differences in stream flow was beyond the scope of the study.

\section{Irrigation efficiencies}

GlobWat calculates the incremental evaporation over areas under irrigation. In the case of paddy rice, an additional volume of water is used for flooding to control weeds. This volume of water can be calculated by multiplying the area under irrigated paddy rice by a water layer of $20 \mathrm{~cm}$. The total irrigation requirements can then be calculated as follows:

$\operatorname{Irr}_{\text {req }}=\left(E_{\text {incr-irr }}(\mathrm{yr}) \times A_{\text {cell }}+0.2 \times A_{\text {paddy }}(\mathrm{yr})\right) \times 10$,

with $\operatorname{Irr}_{\text {req }}$ the total irrigation requirements per year $\left(\mathrm{m}^{3}\right)$, $E_{\text {incr-irr }}(\mathrm{yr})$ the incremental evaporation due to irrigation per year (mm), $A_{\text {cell }}$ the area of the grid cell (ha) and $A_{\text {paddy }}(\mathrm{yr})$ the harvested area under paddy irrigation per year (ha).

In order to calculate irrigation efficiencies, the total irrigation water requirements were compared with the amount of water withdrawn for irrigation as available in AQUASTAT (http://www.fao.org/nr/water/aquastat/data/ query/index.html). Since the years for which AQUASTAT data on water withdrawals generally do not concur with the years for which the cropping calendars are derived, the most recent country values for agricultural water withdrawal were extrapolated towards the year for which cropping calendars are valid. This was done by using the item "Total area equipped for irrigation" as available in FAOSTAT (http: //faostat.fao.org/site/377/default.aspx\#ancor) in Eq. (34):

$Q_{\mathrm{aww}}(\mathrm{yr}-\mathrm{cc})=Q_{\mathrm{aww}}(\mathrm{yr}-\mathrm{aww}) \cdot \operatorname{AEI}(\mathrm{yr}-\mathrm{cc}) / \mathrm{AEI}(\mathrm{yr}-\mathrm{aww})$,

with $Q_{\text {aww }}$ the agricultural water withdrawal per country $\left(\mathrm{m}^{3} \mathrm{yr}^{-1}\right)$, AEI the total area equipped for irrigation per country (ha), yr-cc the year for which a cropping calendar is available, and yr-aww the year with the latest available country values for agricultural water withdrawal. 
Table 3. Input data sets.

\begin{tabular}{lrl}
\hline Map & Resolution & Source \\
\hline Global maps of monthly precipitation & $10 \mathrm{~min}$ & New et al. (2002) \\
\hline Global maps of wet days per month & $10 \mathrm{~min}$ & New et al. (2002) \\
\hline $\begin{array}{l}\text { Global maps of coefficient of variation of } \\
\text { precipitation per month }\end{array}$ & $10 \mathrm{~min}$ & New et al. (2002) \\
\hline $\begin{array}{l}\text { Global maps of monthly reference } \\
\text { evaporation }\end{array}$ & $10 \mathrm{~min}$ & $\begin{array}{l}\text { Calculated according to FAO (Allen et al., 1998) } \\
\text { with input data from New et al. (2002) }\end{array}$ \\
\hline $\begin{array}{l}\text { Maximum soil moisture storage capacity } \\
\text { Maximum groundwater recharge flux }\end{array}$ & $5 \mathrm{~min}$ & $\begin{array}{l}\text { Derived from the Harmonised World } \\
\text { Soil Database, FAO (2012) }\end{array}$ \\
\hline $\begin{array}{l}\text { Land use or vegetation type coefficient }(K c) \\
\text { Global map of irrigation areas }\end{array}$ & $\begin{array}{l}\text { Derived from WHYMAP, BGR and } \\
\text { UNESCO (2008) }\end{array}$ \\
\hline Global map of lakes and wetlands & $\begin{array}{l}\text { Derived from FAO's Global } \\
\text { Agricultural Systems Map, FAO (2011b) }\end{array}$ \\
\hline Global map of river basins and sub-basins & $5 \mathrm{~min}$ & Siebert et al. (2007) \\
\hline
\end{tabular}

The average of the years for which cropping calendar data are available is 2004 , and consequently the calculated outputs of GlobWat as presented here are on average valid for that year. Water withdrawal data in AQUASTAT that were estimated on the basis of earlier model calculations were excluded from the exercise.

Irrigation efficiencies can be calculated by applying Eq. (35) per country for those countries for which country data on agricultural water withdrawals are available. For those countries for which no water withdrawal data are available, irrigation efficiencies have been estimated based on countries nearby with similar conditions with regard to climate and economic development:

$\operatorname{Irr}_{\text {eff }}=\operatorname{Irr}_{\text {req }} / Q_{\text {aww }}$,

with $\operatorname{Irr}_{\text {eff }}$ the irrigation efficiency $(-), \operatorname{Irr}_{\text {req }}$ the total irrigation requirements $\left(\mathrm{m}^{3} \mathrm{yr}^{-1}\right)$ and $Q_{\text {aww }}$ the agricultural water withdrawal $\left(\mathrm{m}^{3} \mathrm{yr}^{-1}\right)$.

\section{Input and output data sets}

The input data sets used are derived from public domain data sets and are found in Table 3.

The results of the water balance calculations consist of monthly values by grid cell for generated precipitation, actual evaporation, incremental evaporation due to irrigated agriculture, surface runoff, groundwater recharge and water stored as soil moisture. Aggregated annual water balances can be calculated for any desired spatial domain (e.g. countries or river basins) and include, apart from the above-mentioned variables, incremental evaporation over open water and incremental evaporation over wetlands.

\section{Model results, calibration and validation}

Water balances have been generated by the model and aggregated for each country to compare them with AQUASTAT data on Internal Renewable Water Resources (IRWR) and "Internally produced groundwater". The internal renewable water resources of a country are defined as "Long-term average annual flow of rivers and recharge of aquifers generated from endogenous precipitation". It corresponds to the sum of surface runoff and groundwater recharge as calculated by the model. Internally produced groundwater is defined as "Longterm annual average groundwater recharge, generated from precipitation within the boundaries of the country", which was compared to the model-generated groundwater recharge (AQUASTAT datadase; FAO, 2013).

Calibration of the model was only undertaken for the "vertical" water balance (step 1 in Fig. 1). Calibration factors were applied for hydrologically more or less uniform AQUASTAT regions as described in "The state of the world's land and water resources for food and agriculture - Managing systems at risk" (FAO, 2011b). Two layers with calibration factors were used, one to adjust (sub-)surface runoff fluxes by multiplying the maximum soil moisture storage capacity, the effective rooting depth and the number of wet days by a calibration factor $\left(\mathrm{Cal}_{\mathrm{sw}}\right)$, and another one to fine-tune groundwater recharge by multiplying the maximum groundwater recharge flux by a groundwater calibration factor $\left(\mathrm{Cal}_{\mathrm{gw}}\right)$. 
Table 4. Calibration factors per hydrological region.

\begin{tabular}{|c|c|c|c|c|c|c|c|c|}
\hline Region & Cal-sw & $\begin{array}{r}\text { IRWR } \\
(\mathrm{mm}) \\
\text { AQUASTAT }\end{array}$ & $\begin{array}{r}\text { Recharge } \\
\text { and drainage } \\
(\mathrm{mm}), \\
\text { modelled }\end{array}$ & $\begin{array}{r}\text { Diff. } \\
(\mathrm{mm})\end{array}$ & Cal-gw & $\begin{array}{r}\text { Ground } \\
\text { water } \\
\text { recharge } \\
(\mathrm{mm}) \\
\text { AQUASTAT }\end{array}$ & $\begin{array}{r}\text { Ground } \\
\text { water } \\
\text { recharge } \\
(\mathrm{mm}), \\
\text { modelled }\end{array}$ & $\begin{array}{r}\text { Diff. } \\
(\mathrm{mm})\end{array}$ \\
\hline Northern Africa & 1.5 & 9 & 8 & 0 & 1.5 & 3 & 2 & 0 \\
\hline Sudano-Sahel & 2 & 19 & 38 & 20 & 1 & 7 & 6 & -1 \\
\hline Gulf of Guinea & 1.7 & 455 & 475 & 20 & 1.5 & 134 & 146 & 11 \\
\hline Central Africa & 1.9 & 353 & 409 & 56 & 1.2 & 156 & 185 & 29 \\
\hline Eastern Africa & 2 & 96 & 138 & 41 & 1.2 & 33 & 34 & 1 \\
\hline Southern Africa & 2 & 57 & 101 & 44 & 1 & 17 & 24 & 7 \\
\hline Indian Ocean islands & 1 & 571 & 590 & 20 & 1 & 94 & 109 & 15 \\
\hline North America & 0.7 & 299 & 268 & -31 & 2.5 & 92 & 84 & -9 \\
\hline Mexico & 1 & 210 & 206 & -4 & 2.5 & 71 & 66 & -5 \\
\hline Central America & 0.7 & 1335 & 1306 & -29 & 2.5 & 397 & 263 & -134 \\
\hline Greater Antilles & 0.9 & 440 & 389 & -51 & 2.2 & 126 & 110 & -15 \\
\hline Lesser Antilles & 0.9 & 218 & 386 & 168 & 2.2 & 141 & 108 & -33 \\
\hline Guyanas & 0.9 & 1051 & 1109 & 58 & 2.5 & 512 & 333 & -179 \\
\hline Andes & 0.7 & 1106 & 1041 & -64 & 2.5 & 278 & 194 & -84 \\
\hline Brazil & 1 & 638 & 761 & 123 & 2 & 221 & 311 & 91 \\
\hline South America & 0.7 & 322 & 347 & 25 & 2.5 & 81 & 54 & -27 \\
\hline Arabian Peninsula & 2 & 2 & 7 & 4 & 2.5 & 2 & 0 & -2 \\
\hline Caucasus & 0.6 & 393 & 359 & -34 & 2.5 & 151 & 72 & -79 \\
\hline Iran & 0.6 & 79 & 102 & 22 & 2.5 & 30 & 11 & -20 \\
\hline Near East & 0.7 & 181 & 163 & -18 & 2.5 & 54 & 47 & -7 \\
\hline Central Asia & 0.7 & 57 & 73 & 16 & 2.5 & 9 & 22 & 13 \\
\hline South Asia & 0.9 & 465 & 537 & 72 & 2.5 & 130 & 81 & -49 \\
\hline East Asia & 0.7 & 296 & 227 & -69 & 2.5 & 77 & 57 & -20 \\
\hline Mainland Southeast Asia & 0.8 & 993 & 987 & -5 & 2.5 & 326 & 200 & -126 \\
\hline Maritime Southeast Asia & 0.9 & 1323 & 1436 & 113 & 1 & 282 & 276 & -6 \\
\hline Northern Europe & 0.55 & 687 & 555 & -133 & 2 & 120 & 112 & -8 \\
\hline Western Europe & 0.7 & 444 & 469 & 25 & 1 & 143 & 130 & -13 \\
\hline Central Europe & 0.75 & 228 & 223 & -5 & 1 & 64 & 75 & 11 \\
\hline Mediterranean Europe & 0.7 & 391 & 367 & -24 & 2.4 & 89 & 97 & 9 \\
\hline Russian Federation & 0.55 & 257 & 264 & 7 & 1.2 & 47 & 51 & 4 \\
\hline Eastern Europe & 0.75 & 135 & 154 & 18 & 1 & 45 & 59 & 14 \\
\hline Australia and New Zealand & 1 & 103 & 102 & -1 & 1 & 9 & 11 & 1 \\
\hline Pacific Islands & 0.7 & 1802 & 1779 & -23 & 2 & - & - & - \\
\hline
\end{tabular}

$\mathrm{Cal}_{\mathrm{sw}}$ varies from 0.55 to 2 and $\mathrm{Cal}_{\mathrm{gw}}$ from 1 to 2.5 . The results of the calibration are presented in Table 4.

Validation of the model output was accomplished by comparing average river discharges of the Global River Discharge Database (Center for Sustainability and the Global Environment, 2014). The stations with discharge data in the Global River Discharge Database are not always located at the mouth of the river basin. Therefore the specific discharge, defined as the total annual discharge divided by the area over which the discharge is generated, was calculated for the stations situated as close as possible to the mouth of the river. The specific discharges per station were then compared with the specific discharge per river basin as derived from the modelled data. Table 5 shows the result of this valida- tion exercise for 51 river basins with an area greater than $100000 \mathrm{~km}^{2}$. Figure 2 shows the same results in a graph.

The total area weighted average specific discharge as measured over the above-listed river basins is $332 \mathrm{~mm}$ per year. The area weighted average difference (observed minus simulated) in specific discharges is $2 \mathrm{~mm}$, which indicates that the model underestimates the total discharge over all river basins by $0.7 \%$.

The model results have also been evaluated against the three quantitative statistical indicators recommended by Moriasi et al. (2007): the above-listed results have a NashSutcliffe efficiency (NSE) of 0.90 (where 1 would be the ideal model), a percent bias (PBIAS) of $-3.0 \%$ (not taking into account the area of the basin, the model overestimates, on average per basin, the discharge by $3.0 \%$ ), and a root 
Table 5. Validation results per river basin.

\begin{tabular}{|c|c|c|c|c|c|c|c|}
\hline \multirow[t]{2}{*}{ River basin } & \multicolumn{3}{|c|}{ Measured } & \multicolumn{3}{|c|}{ Modelled } & \multirow{2}{*}{$\begin{array}{r}\text { Difference } \\
\text { in specific } \\
\text { discharge } \\
(\mathrm{mm})\end{array}$} \\
\hline & $\begin{array}{r}\text { Discharge } \\
\left(\mathrm{m}^{3} \mathrm{~s}^{-1}\right)\end{array}$ & $\begin{array}{r}\text { Upstream } \\
\text { area } \\
\left(\mathrm{km}^{2}\right)\end{array}$ & $\begin{array}{r}\text { Specific } \\
\text { discharge } \\
(\mathrm{mm})\end{array}$ & $\begin{array}{r}\text { Basin } \\
\text { area } \\
\left(\mathrm{km}^{2}\right)\end{array}$ & $\begin{array}{r}\text { Total } \\
\text { outflow } \\
\left(\mathrm{m}^{3} \mathrm{~s}^{-2}\right)\end{array}$ & $\begin{array}{r}\text { Specific } \\
\text { discharge } \\
(\mathrm{mm})\end{array}$ & \\
\hline Amazon & 171663 & 4618746 & 1172 & 5987204 & 209190 & 1102 & 70 \\
\hline Congo & 40192 & 3475000 & 365 & 3712251 & 43154 & 367 & -2 \\
\hline Mississippi-Missouri & 17031 & 2964254 & 181 & 3265753 & 21829 & 211 & -30 \\
\hline Nile & 2744 & 3080000 & 28 & 3083546 & 2733 & 28 & 0 \\
\hline $\mathrm{Ob}$ & 12475 & 2430000 & 162 & 3010822 & 13422 & 141 & 21 \\
\hline Yenisey & 17682 & 2440000 & 229 & 2561252 & 19465 & 240 & -11 \\
\hline Lena & 16621 & 2430000 & 216 & 2401442 & 14553 & 191 & 25 \\
\hline Niger & 1149 & 1000000 & 36 & 2142881 & 7516 & 111 & -74 \\
\hline Amur & 9739 & 1730000 & 178 & 2079157 & 14103 & 214 & -36 \\
\hline Yangtze & 25031 & 1705383 & 463 & 1791327 & 23602 & 416 & 47 \\
\hline Mackenzie & 8343 & 1570000 & 168 & 1755147 & 2801 & 50 & 117 \\
\hline Ganges-Bramaputra & 30796 & 1483030 & 655 & 1669861 & 26724 & 505 & 150 \\
\hline Volga & 8086 & 1360000 & 188 & 1466717 & 12280 & 264 & -77 \\
\hline St Lawrence & 6881 & 764600 & 284 & 1304701 & 14687 & 355 & -71 \\
\hline Saskatchewan-Nelson & 2402 & 1000000 & 76 & 1131261 & 607 & 17 & 59 \\
\hline Syr Darya & 541 & 219000 & 78 & 1113531 & 0 & 0 & 78 \\
\hline Orange & 157 & 850530 & 6 & 986696 & 383 & 12 & -6 \\
\hline Orinoco & 28723 & 850000 & 1066 & 976688 & 39807 & 1285 & -220 \\
\hline Murray-Darling & 256 & 991000 & 8 & 929640 & 889 & 30 & -22 \\
\hline Tocantins & 12173 & 758000 & 506 & 916945 & 21781 & 749 & -243 \\
\hline Tigris-Euphrates & 1570 & 408100 & 121 & 915121 & 1336 & 46 & 75 \\
\hline Indus & 2396 & 832418 & 91 & 868766 & 137 & 5 & 86 \\
\hline Huang $\mathrm{He}$ & 1209 & 688421 & 55 & 832699 & 1671 & 63 & -8 \\
\hline Mekong & 7994 & 391000 & 645 & 803765 & 16814 & 660 & -15 \\
\hline Amu Darya & 1500 & 450000 & 105 & 798035 & 0 & 0 & 105 \\
\hline Danube & 6498 & 807000 & 254 & 797546 & 6770 & 268 & -14 \\
\hline Colorado, North America & 463 & 289562 & 50 & 650653 & 631 & 31 & 20 \\
\hline Sao Francisco & 2817 & 510800 & 174 & 638834 & 2624 & 130 & 44 \\
\hline Rio Grande-Bravo & 69 & 459902 & 5 & 552282 & 404 & 23 & -18 \\
\hline Dnieper & 1483 & 463000 & 101 & 511573 & 2214 & 137 & -35 \\
\hline Senegal & 665 & 218000 & 96 & 478482 & 882 & 58 & 38 \\
\hline Don & 787 & 378000 & 66 & 443541 & 2678 & 190 & -125 \\
\hline Xun Jiang & 7084 & 329705 & 678 & 412937 & 9198 & 702 & -25 \\
\hline Volta & 1124 & 394100 & 90 & 412735 & 1971 & 151 & -61 \\
\hline Limpopo & 75 & 196000 & 12 & 411728 & 88 & 7 & 5 \\
\hline Colorado, South America & 104 & 22300 & 147 & 374438 & 681 & 57 & 90 \\
\hline Parnaiba & 842 & 282000 & 94 & 332770 & 1384 & 131 & -37 \\
\hline Godavari & 3061 & 299320 & 323 & 314617 & 4534 & 455 & -132 \\
\hline Krishna & 1641 & 251355 & 206 & 274596 & 1546 & 178 & 28 \\
\hline Northern Dvina & 3315 & 348000 & 300 & 273375 & 3128 & 361 & -60 \\
\hline Magdalena & 6973 & 257438 & 854 & 260535 & 8646 & 1047 & -192 \\
\hline Neva & 2511 & 281000 & 282 & 227929 & 2471 & 342 & -60 \\
\hline Wisla & 1056 & 194376 & 171 & 192953 & 920 & 150 & 21 \\
\hline Rhine & 2291 & 159680 & 452 & 186771 & 2361 & 399 & 54 \\
\hline Negro & 762 & 95000 & 253 & 161660 & 990 & 193 & 60 \\
\hline Chao Phraya & 776 & 110569 & 221 & 157633 & 1528 & 306 & -84 \\
\hline Mahandi & 1883 & 132090 & 450 & 145260 & 2893 & 628 & -178 \\
\hline Elbe & 744 & 123532 & 190 & 140390 & 883 & 198 & -9 \\
\hline Grijalva-Usumacinta & 2030 & 47697 & 1342 & 132063 & 4386 & 1047 & 295 \\
\hline Oder & 536 & 109729 & 154 & 120587 & 567 & 148 & 6 \\
\hline Loire & 835 & 110000 & 239 & 116573 & 1191 & 322 & -83 \\
\hline
\end{tabular}




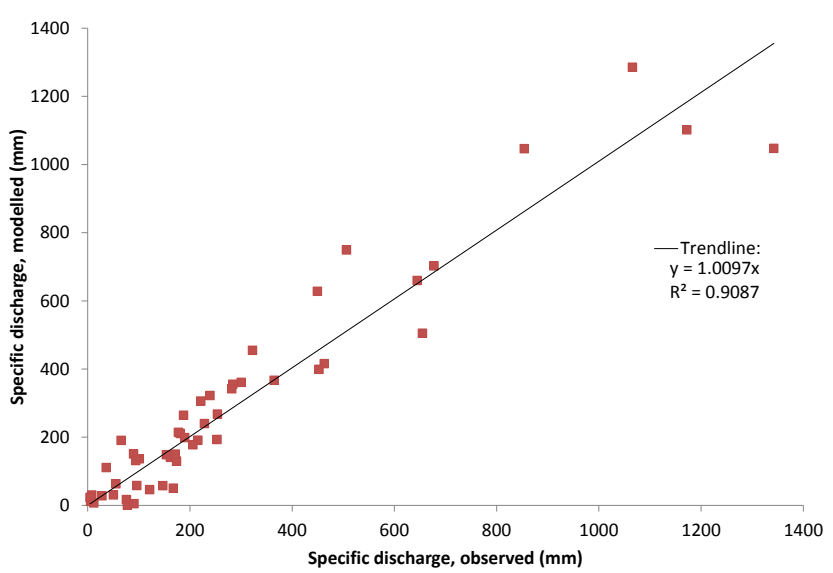

Figure 2. Graphic representation of validation results in which modelled specific river discharges are compared to observed specific river discharges.

mean square error-standard deviation ratio (RSR) of 0.31 (the RSR can vary from the optimal value of 0 - no residual variation, so perfect simulation - to a large positive value). According to Moriasi et al. (2007), model simulation can be judged as satisfactory if NSE $>0.50$, PBIAS $< \pm 25 \%$, and $\mathrm{RSR}<0.70$.

The outputs of the model are global raster maps with a resolution of 5 arcmin containing monthly information on generated precipitation, total actual evaporation from the soil water balance component, incremental evaporation from irrigation, incremental evaporation from lakes and wetlands, (sub-)surface runoff and groundwater recharge. The output maps are available on FAO's AQUAMAPS website: http: //www.fao.org/nr/water/aquamaps/.

As an example, Fig. 3 shows total yearly actual evaporation (the sum of actual evaporation from the soil water balances and incremental evaporation from irrigated areas, lakes and wetlands).

Figure 4 shows the calculated accumulated outflow per sub-basin. Since the HydroSHEDS database does not provide data above $60^{\circ}$ northern latitude, and due to the fact that in these areas population densities are generally low, the mapped sub-basins are of a lower spatial resolution, which can be seen in Greenland and the northern-flowing river basins in Siberia (e.g. Ob, Lena, Yenissey).

Apart from maps, the model also calculates aggregated results per country, per major basin and per sub-basin. As an example, the total global water balance as calculated by GlobWat is presented in Table 6 .

In Table 7, incremental evaporation due to irrigation as calculated by GlobWat; total irrigation water requirements; amounts of water withdrawn for irrigation as available in AQUASTAT (http://www.fao.org/nr/water/aquastat/ data/query/index.html); and irrigation efficiencies, are presented for the hydrological regions. Since more or less reliable water withdrawal data per country are available for less
Table 6. Global terrestrial water balance.

\begin{tabular}{lrr}
\hline & $10^{9} \mathrm{~m}^{3}$ & $(\mathrm{~mm})$ \\
\hline Precipitation & 105316 & $(805)$ \\
Rainfed evaporation & 61106 & $(467)$ \\
Renewable water resources & 44211 & $(338)$ \\
Incremental evaporation over open water & 1184 & $(9)$ \\
Incremental evaporation over wetlands & 2899 & $(22)$ \\
Incremental evaporation from irrigation & 1268 & $(10)$ \\
Outflow to sea & 38859 & $(297)$ \\
\hline
\end{tabular}

than $50 \%$ of the countries included in this analysis, it was decided to present water use efficiency values for hydrological regions only rather than for individual countries.

Figure 5 shows the distribution of global water stress by major river basin based on incremental evaporation caused by irrigation as a percentage of total generated groundwater and surface water resources. Levels of water stress are often classified by using the Millennium Development Goals Water Indicator. The MDG Water Indicator measures water stress per country on the ratio between total water withdrawn and total renewable water resources (UN, 2008; FAO, 2013). Using this indicator, it is estimated that a withdrawal rate above $20 \%$ of renewable water resources represents "substantial" pressure on water resources, while more than $40 \%$ is considered "critical" (FAO 2011b). Other classifications use thresholds of 0-10\% no stress, 10-20\%, low stress, 20 $40 \%$ moderate stress, and more than $40 \%$ severe stress (UN, 1997). The mentioned stress classifications include all water withdrawals. Taking into account that agriculture accounts for more than $90 \%$ of the consumptive use of global water withdrawals (FAO, 2012), and that on average incremental evaporation due to irrigation is about half of irrigation water withdrawals (Table 8), it is possible to assume thresholds of water stress classes based on incremental evaporation that are half of the thresholds based on water withdrawals. Water stress can then be considered substantial when incremental evaporation caused by irrigation exceeds $10 \%$ of the generated water resources in a river basin. River basins in which the incremental evaporation caused by irrigation exceeds $20 \%$ should be considered critically stressed.

\section{Discussion and conclusion}

Modelling exercises, performed with earlier versions of the model and with other input data sets, have been used by FAO on several occasions and were documented in the following FAO perspective studies: World agriculture: towards 201530; an FAO perspective (Bruinsma, 2003), World Agriculture - Towards 2030 and 2050 (FAO, 2006), World Agriculture Towards 2050 and 2080 (FAO, 2011a), and the global assessment of water use and availability carried out for The State of the World's Land and Water Resources for Food and Agri- 

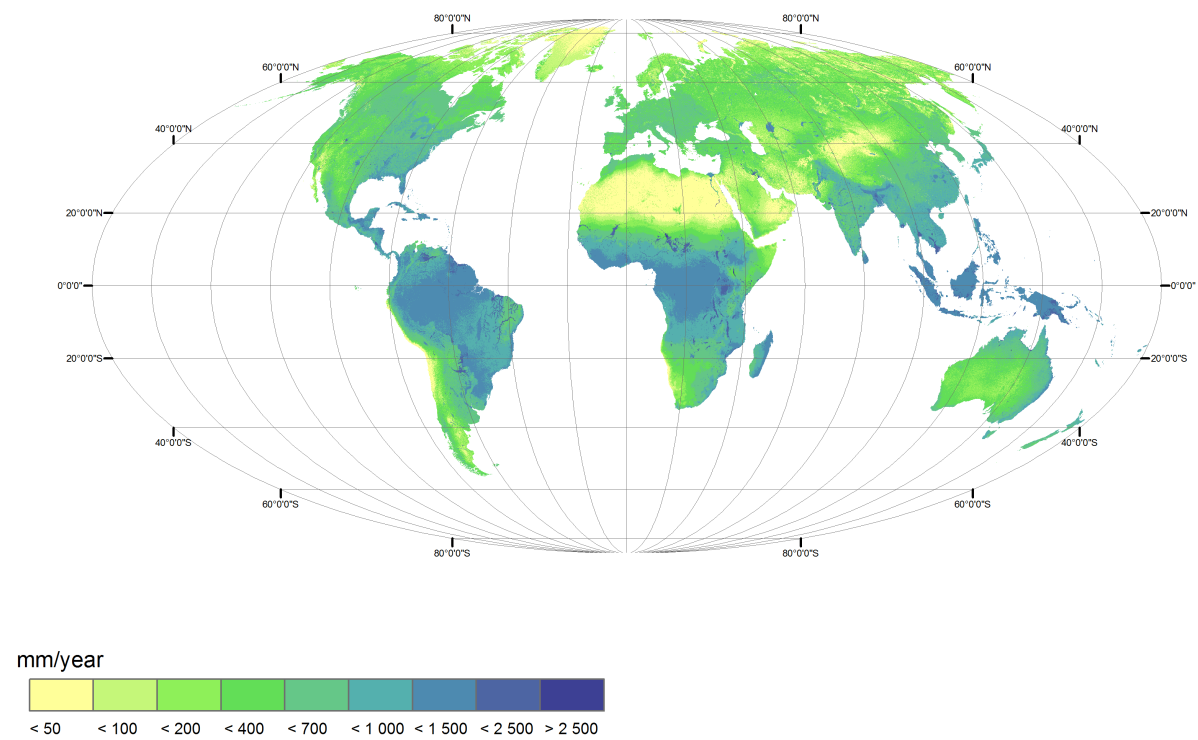

Figure 3. Average global actual evaporation per year.
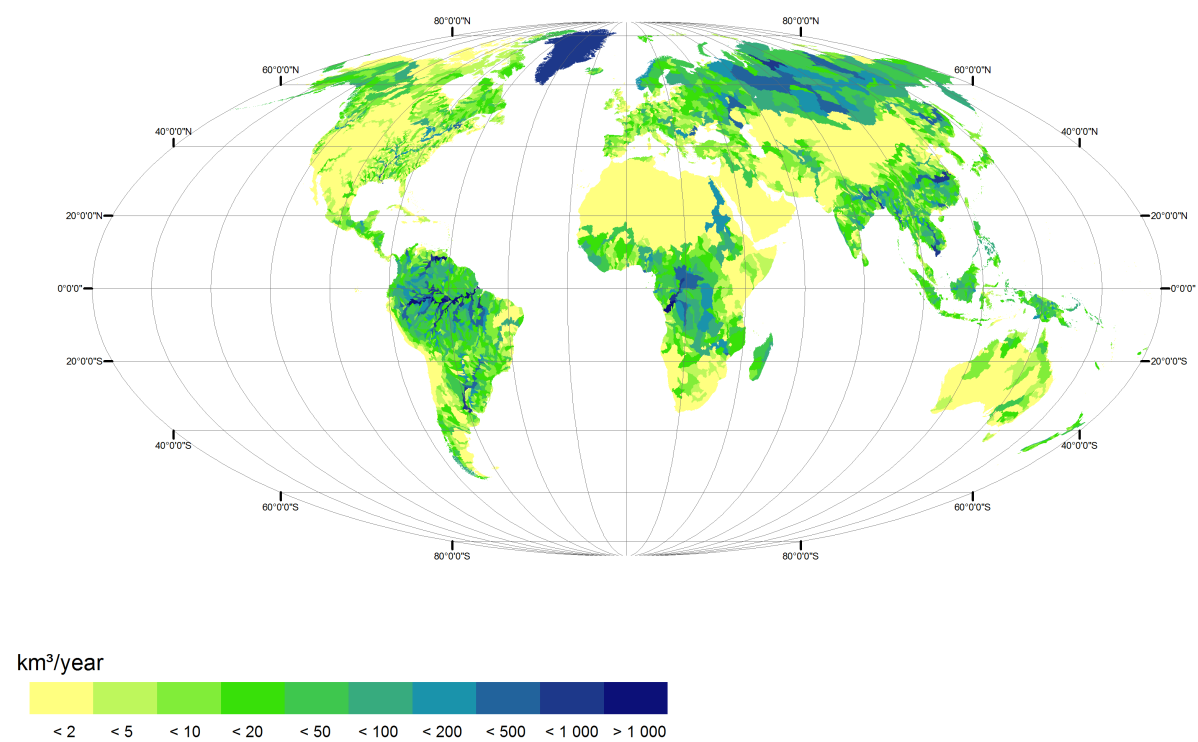

Figure 4. Average annual outflow per sub-basin.

culture (FAO, 2011b). However, the model results were never systematically compared with the outputs of other models. For this article, the output of GlobWat is compared with models WaterGAP, WBMplus, GEPIC, LPJmL, PCR-GLOBWB and GCWM as mentioned in the introduction of this article. In Table 8 the calculated amount of water used in agriculture for these models is compared with the results of GlobWat. Values for the incremental evaporation due to irrigation for all models except PCR-GLOBWB were found in Hoff et al. (2010). Values for the incremental evaporation due to irrigation PCR-GLOBWB, and values on water withdrawal for irrigation, were found in the references mentioned above.
Table 8 shows that the values of "incremental evaporation due to irrigation" are fairly similar among the different models (except for GEPIC, which shows significantly lower results than the other models). With regard to the "water withdrawals for irrigation", the results of GlobWat and LPJmL are very similar, and, to a lesser extent, so are the results from WaterGap2 and WBMplus. This implies that the irrigation efficiencies as assumed by WaterGAP2 and WBMplus (around $38 \%$ ) are significantly lower than those from GlobWat and LPJmL (around 50\%). Irrigation efficiencies for PCR-GLOBWB are in between these values at around $41 \%$. The calculated irrigation efficiency for GlobWat $(55 \%)$ is higher than the irrigation efficiencies for all other models. 

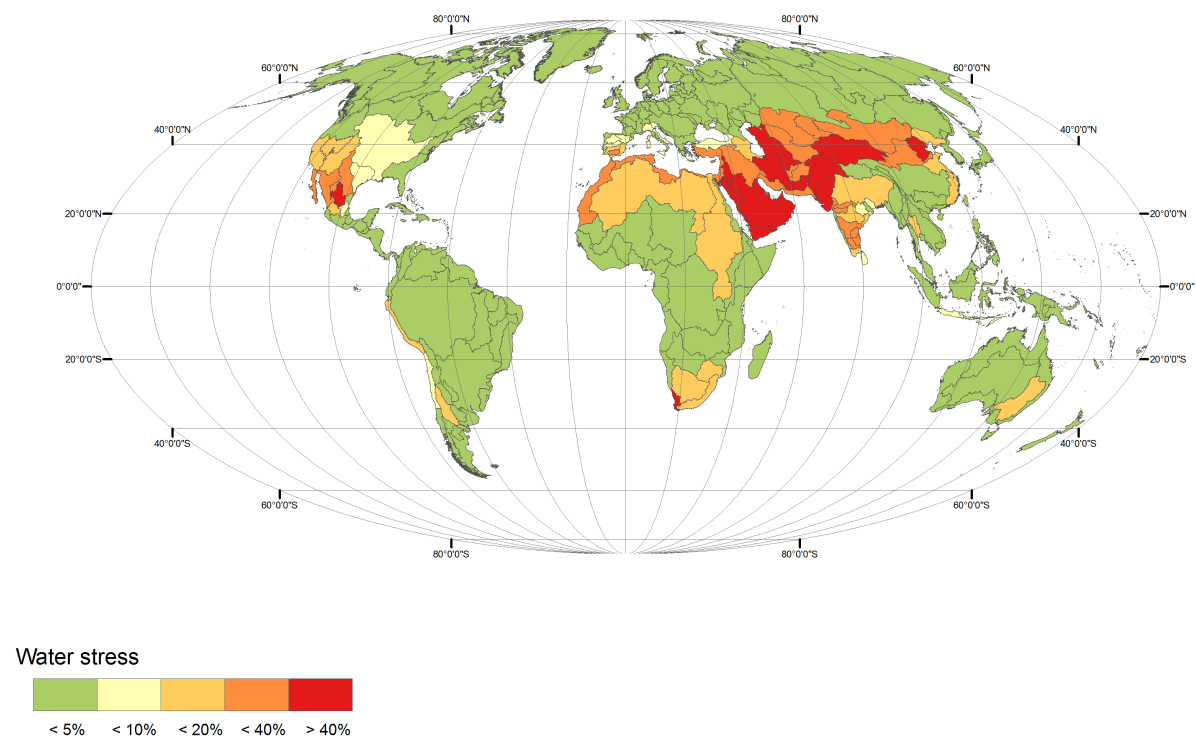

Figure 5. Water stress per major river basin expressed as a percentage of incremental evaporation due to irrigation over generated groundwater and surface water resources.

This is mainly due to the fact that for GlobWat also the water requirements for flooding paddy rice are incorporated into the irrigation water requirements. If the irrigation efficiency of GlobWat would be calculated as incremental evaporation divided by water withdrawals, it would result in a value of $48 \%$.

In addition to the higher resolution as compared to most other global (agro)hydrological models, GlobWat differs from these models in the explicit differentiation between evaporation from in situ rainfall and incremental evaporation occurring over wetlands, open water and irrigated areas of water that is conveyed from elsewhere. This distinction is especially useful for differentiating between the part of the evaporation that can be influenced only through land management (evaporation from in situ rainfall or "green water") and the part of the evaporation that is influenced through water management (incremental evaporation or "blue water").

For "open water" and "swamps and wetlands" GlobWat makes, unlike other models, a clear distinction between the "vertical" water balance, attributable to in situ rainfall, and the "horizontal" balance, attributable to lateral flow. This distinction is not only important in terms of the internal consistency of the model concept over all land cover classes, it is especially relevant for the calculation of renewable water resources. In the model, renewable water resources are calculated as the sum of all generated groundwater and surface water, which equals precipitation minus evaporation from in situ precipitation. If the precipitation exceeds evaporation, the precipitation surplus over open water and wetlands contributes to the renewable water resources. However, if evaporation exceeds precipitation over open water and wetlands, (the evaporation "surplus"), the incremental evaporation over open water and wetlands is not incorporated into the calculation of generated renewable water resources. This is necessary to account for water resources generated in internal river basins, which would otherwise be classified as having no renewable water resources at all.

Excluding the incremental evaporation over wetlands and open water has as a consequence that some river basins in Fig. 5 (e.g. the Nile River basin) seem to be less stressed than is apparent. In the case of the Nile basin, the lower than expected stress levels are due to water losses over wetlands and open water. According to the GlobWat results, more than $50 \%$ of all the water resources that are generated in the Nile River basin evaporate as incremental evaporation over open water and wetlands, specifically over the Sudd wetlands.

In conclusion, GlobWat is a simple model that has been designed specifically to assess the impact of irrigated agriculture on the global hydrological cycle. The model was calibrated using country-level data on total internal renewable water resources and groundwater resources, and validated with discharge data from major river basins. The model has a high resolution of $5 \mathrm{~min}$ and distinguishes between evaporation from in situ rainfall and from water transported in from elsewhere. Model outputs include estimates of consumptive water use by agriculture which were compared with AQUASTAT country data on water withdrawals for agriculture to calculate irrigation efficiencies.

GlobWat, including all input data sets, will be made freely available for download at FAO's AquaMaps website: http: //www.fao.org/nr/water/aquamaps/. 
Table 7. Water use in agriculture per hydrological region.

\begin{tabular}{|c|c|c|c|c|}
\hline Region & $\begin{array}{r}\text { Incremental } \\
\text { evaporation due } \\
\text { to irrigation } \\
\left(10^{6} \mathrm{~m}^{3}\right)\end{array}$ & $\begin{array}{r}\text { Total } \\
\text { irrigation } \\
\text { requirements } \\
\left(10^{6} \mathrm{~m}^{3}\right)\end{array}$ & $\begin{array}{l}\text { Irrigation } \\
\text { "efficiency"* }\end{array}$ & $\begin{array}{r}\text { Irrigation } \\
\text { water } \\
\text { withdrawals } \\
\left(10^{6} \mathrm{~m}^{3}\right)\end{array}$ \\
\hline Northern Africa & 55975 & 57291 & $69 \%$ & 83388 \\
\hline Sudano-Sahel & 11019 & 11608 & $42 \%$ & 27825 \\
\hline Gulf of Guinea & 2077 & 2203 & $43 \%$ & 5183 \\
\hline Central Africa & 241 & 272 & $24 \%$ & 1151 \\
\hline Eastern Africa & 2773 & 3033 & $25 \%$ & 12294 \\
\hline Southern Africa & 8730 & 8767 & $41 \%$ & 21283 \\
\hline Indian Ocean islands & 2273 & 4398 & $21 \%$ & 21220 \\
\hline North America & 108903 & 111072 & $56 \%$ & 199842 \\
\hline Mexico & 25902 & 26034 & $43 \%$ & 61200 \\
\hline Central America & 3726 & 3920 & $48 \%$ & 8246 \\
\hline Greater Antilles & 1863 & 2348 & $38 \%$ & 6181 \\
\hline Lesser Antilles & 56 & 104 & $38 \%$ & 274 \\
\hline Guyanas & 346 & 711 & $36 \%$ & 1992 \\
\hline Andes & 16912 & 18225 & $31 \%$ & 58129 \\
\hline Brazil & 13038 & 15296 & $48 \%$ & 31700 \\
\hline South America & 18452 & 19303 & $51 \%$ & 37570 \\
\hline Arabian Peninsula & 20936 & 20936 & $57 \%$ & 36741 \\
\hline Caucasus & 4492 & 4492 & $37 \%$ & 12224 \\
\hline Iran & 47929 & 49185 & $55 \%$ & 88844 \\
\hline Near East & 49854 & 50092 & $51 \%$ & 98361 \\
\hline Central Asia & 59853 & 60621 & $47 \%$ & 127883 \\
\hline South Asia & 469665 & 531646 & $58 \%$ & 909744 \\
\hline East Asia & 205531 & 269871 & $71 \%$ & 382570 \\
\hline Mainland Southeast Asia & 47670 & 79094 & $46 \%$ & 173709 \\
\hline Maritime Southeast Asia & 30242 & 57469 & $39 \%$ & 148697 \\
\hline Northern Europe & 813 & 813 & $58 \%$ & 1397 \\
\hline Western Europe & 4497 & 4497 & $72 \%$ & 6282 \\
\hline Central Europe & 1107 & 1115 & $42 \%$ & 2668 \\
\hline Mediterranean Europe & 29552 & 30358 & $69 \%$ & 43765 \\
\hline Russian Federation & 8949 & 9227 & $42 \%$ & 22071 \\
\hline Eastern Europe & 2300 & 2342 & $42 \%$ & 5602 \\
\hline Australia and New Zealand & 12051 & 12089 & $64 \%$ & 18787 \\
\hline Pacific Islands & 0 & 0 & - & 0 \\
\hline World & 1267727 & 1468433 & $55 \%$ & 2656825 \\
\hline
\end{tabular}

${ }^{*}$ Calculated according to Eq. (35).

Table 8. Global water use in agriculture as calculated by different models.

\begin{tabular}{lccclll}
\hline Model & $\begin{array}{c}\text { Water } \\
\text { withdrawals } \\
\text { for irrigation } \\
\left(\mathrm{km}^{3} \mathrm{yr}^{-1}\right)\end{array}$ & $\begin{array}{c}\text { Total } \\
\text { irrigation } \\
\text { requirements } \\
\left(\mathrm{km}^{3} \mathrm{yr}^{-1}\right)\end{array}$ & $\begin{array}{c}\text { Incremental } \\
\text { evaporation } \\
\text { due to } \\
\text { irrigation } \\
\left(\mathrm{km}^{3} \mathrm{yr}^{-1}\right)\end{array}$ & $\begin{array}{l}\text { Reference } \\
\text { year }\end{array}$ & $\begin{array}{c}\text { Spatial } \\
\text { resolution }\end{array}$ & $\begin{array}{c}\text { Irrigation } \\
\text { efficiency }\end{array}$ \\
\hline GlobWat & 2657 & 1468 & 1268 & On average, 2004 & 5 arcmin & $55 \%$ \\
WaterGAP2 & 3594 & - & 1300 & 1995 & $30 \operatorname{arcmin}$ & $36 \%$ \\
WBMplus & 3250 & - & 1301 & $1998-2002$ & 30 arcmin & $40 \%$ \\
LPJmL & 2650 & - & 1364 & $1981-2000$ & 30 arcmin & $51 \%$ \\
GEPIC & - & - & 927 & 2000 & $30 \operatorname{arcmin}$ & - \\
GCWM & - & - & 1180 & $1998-2000$ & 5 arcmin & - \\
PCR-GLOBWB & 2885 & - & 1179 & 2000 & $30 \operatorname{arcmin}$ & $41 \%$ \\
(CRU TS2.1 & & & & & & \\
ref. scen.) & & & & & & \\
\hline
\end{tabular}


Edited by: J. Liu

\section{References}

Alcamo, J., Flörke, M., and Märker, M.: Future long-term changes in global water resources driven by socio-economic and climatic changes, Hydrolog. Sci. J., 52, 247-275, 2007.

Allen, R. G., Pereira, L. S., Raes, D., and Smith, M.: Crop evapotranspiration, Guidelines for computing crop water requirements, Irrigation and Drainage Paper 56, Food and Agriculture Organization of the United Nations, Rome, Italy, 1998.

BGR and UNESCO: World-wide Hydrogeological Mapping and Assessment Programme (WHYMAP), Hannover, Germany, 2008.

Biemans, H.: Water constraints on future food production, Wageningen University dissertation no. 5319, Wageningen, the Netherlands, 2012

Bruinsma, J. (Ed.): World agriculture: towards 2015/2030, An FAO perspective, Earthscan, London, UK and Food and Agriculture Organization of the United Nations, Rome, Italy, 2003.

Center for Sustainability and the Global Environment (SAGE): Global River Discharge Database, http://www.sage.wisc.edu/ riverdata/, last access: 12 March 2014.

De Zeeuw, J. W.: Hydrograph analysis for areas with mainly groundwater runoff, in: Drainage Principle and Applications, Vol. II, Chapter 16, Theories of field drainage and watershed runoff, Publication 16, International Institute for Land Reclamation and Improvement (ILRI), Wageningen, The Netherlands, 321-358, 1973.

Döll, P. and Fiedler, K.: Global-scale modeling of groundwater recharge, Hydrol. Earth Syst. Sci., 12, 863-885, doi:10.5194/hess-12-863-2008, 2008.

Evans, R., Cassel, D. K., and Sneed, R. E.: Soil, water, and crop characteristics important to irrigation scheduling, Publication No. AG 452-1, North Carolina Cooperative Extension Service, Raleigh, North Carolina, 1996.

Falkenmark, M. and Rockström, J.: Balancing Water for Humans and Nature, The New Approach in Ecohydrology, Earthscan, London, UK, 247 pp., 2004.

FAO: Effective rainfall in irrigated agriculture, Food and Agriculture Organization of the United Nations, Rome, Italy, 1978.

FAO: World agriculture: towards 2030/2050, Interim report, Food and Agriculture Organization of the United Nations, Rome, Italy, 2006.

FAO: World agriculture: towards 2050/2080, Food and Agriculture Organization of the United Nations, Rome, Italy, 2011a.

FAO: State of the world's land and water resources for food and agriculture (SOLAW), Managing systems at risk, Food and Agriculture Organization of the United Nations, Rome, Italy and Earthscan, London, UK, 2011b.

FAO: Coping with water scarcity - An action framework for agriculture and food security, Food and Agriculture Organization of the United Nations, Rome, Italy, 2012.

FAO: AQUASTAT database, Food and Agriculture Organization of the United Nations, Rome, Italy, http://www.fao.org/nr/water/ aquastat/main/index.stm (last access: 12 March 2015), 2013.

FAO/IIASA: Global Agro-Ecological Zones database, Food and Agriculture Organization of the United Nations, Rome, Italy and
IIASA, Laxenburg, Austria, http://gaez.fao.org/Main.html (last access: 30 November 2014), 2012.

FAO/IIASA/ISRIC/ISSCAS/JRC: Harmonized World Soil Database (version 1.2), Food and Agriculture Organization of the United Nations, Rome, Italy and IIASA, Laxenburg, Austria, 2012.

Hoekstra, A. Y. and Chapagain, A. K.: Water footprints of nations: Water use by people as a function of their consumption pattern, Water Resour. Manage., 21, 35-48, 2007.

Hoff, H., Falkenmark, M., Gerten, D., Gordon, L., Karlberg, L., and Rockström, J.: Greening the global water system, J. Hydrol., 384, 177-186, 2010.

Hunger, M. and Döll, P.: Value of river discharge data for globalscale hydrological modeling, Hydrol. Earth Syst. Sci., 12, 841861, doi:10.5194/hess-12-841-2008, 2008.

Lehner, B. and Döll, P.: Development and validation of a global database of lakes, reservoirs and wetlands, J. Hydrol., 296, 1-22, 2004.

Liu, J.: A GIS-based tool for modelling large-scale crop-water relations, Environ. Modell. Softw., 24, 411-422, 2009.

Liu, J. and Yang, H.: Spatially explicit assessment of global consumptive water uses in cropland: Green and blue water, J. Hydrol., 384, 187-197, 2010.

Moriasi, D. N., Arnold, J. G., Van Liew, M. W., Bingner, R. L., Harmel, R. D., and Veith, T. L.: Model evaluation guidelines for systematic quanti?cation of accuracy in watershed simulations, Trans. ASABE, 50, 885-900, 2007.

New, M., Lister, D., Hulme, M., and Makin, I.: A high-resolution data set of surface climate over global land areas, Clim. Res., 21, 1-25, 2002.

Portmann, F., Siebert, S., Bauer, C., and Döll, P.: Global data set of monthly growing areas of 26 irrigated crops, Frankfurt Hydrology Paper 06, Institute of Physical Geography, University of Frankfurt, Frankfurt am Main, Germany, 2008.

Raes, D., Steduto, P., Hsiao, T. C., and Fereres, E.: Reference Manual AquaCrop Version 4.0, Food and Agriculture Organization of the United Nations, Rome, Italy, 2012

Rost, S., Gerten, D., Bondeau, A., Lucht, W., Rohwer, J., and Schaphoff, S.: Agricultural green and blue water consumption and its influence on the global water system, Water Resour. Res., 44, W09405, doi:10.1029/2007WR006331, 2008.

Savenije, H. H. G.: The importance of interception and why we should delete the term evapotranspiration from our vocabulary, Hydrol. Process., 18, 1507-1511, 2004.

Schoof, J. T. and Pryor, S. C.: On the Proper Order of Markov Chain Model for Daily Precipitation Occurrence in the Contiguous United States, J. Appl. Meteorol. Clim., 47, 2477-2486, 2008.

Siebert, S. and Döll, P.: The Global Crop Water Model (GCWM): Documentation and first results for irrigated crops, Frankfurt Hydrology Paper 07, Institute of Physical Geography, University of Frankfurt, Frankfurt am Main, Germany, 2008.

Siebert, S. and Döll, P.: Quantifying blue and green virtual water contents in global crop production as well as potential production losses without irrigation, J. Hydrol., 384, 198-217, 2010.

Siebert, S., Döll, P., Feick, S., Hoogeveen, J., and Frenken K.: Global Map of Irrigation Areas version 4.0.1, Johann Wolfgang Goethe University, Frankfurt am Main, Germany and Food 
and Agriculture Organization of the United Nations, Rome, Italy, 2007.

Siebert, S., Burke, J., Faures, J. M., Frenken, K., Hoogeveen, J., Döll, P., and Portmann, F. T.: Groundwater use for irrigation - a global inventory, Hydrol. Earth Syst. Sci., 14, 1863-1880, doi:10.5194/hess-14-1863-2010, 2010.

Siebert, S., Henrich, V., Frenken, K., and Burke, J.: Update of the digital global map of irrigation areas to version 5, Rheinische Friedrich-Wilhelms-Universität, Bonn, Germany and Food and Agriculture Organization of the United Nations, Rome, Italy, 2013.

Steenhuis, T. S. and van der Molen, W. H.: The ThornthwaiteMather Procedure as a Simple Engineering Method to Predict Recharge, J. Hydrol., 84, 221-229, 1986.

$\mathrm{UN}$ : Comprehensive assessment of the freshwater resources of the world - Report of the Secretary-General, United Nations Department of Economic and Social Affairs, New York, 1997.

UN: Official list of MDG indicators, United Nations, New York, 2008.
Wada, Y., Wisser, D., and Bierkens, M. F. P.: Global modeling of withdrawal, allocation and consumptive use of surface water and groundwater resources, Earth Syst. Dynam., 5, 15-40, doi:10.5194/esd-5-15-2014, 2014.

Wilks, D. S. and Wilby, R. L.: The weather generation game: a review of stochastic weather models, Prog. Phys. Geogr., 23, 329357, 1999.

Wisser, D., Frolking, S., Douglas, M. E., Fekete, B. M., Schumann, A. H., and Vörösmarty, C. J.: Blue and green water: The significance of local water resources captured in small reservoirs for crop production - a global scale analysis, J. Hydrol., 384, 264 275, 2010.

Wood, E. F., Roundy, J. K., Troy, T. J., van Beek, L. P. H., Bierkens, M. F. P., Blyth, E., de Roo, A., Döll, P., Ek, M., Famiglietti, J., Gochis, D., van de Giesen, N., Houser, P., Jaffé, P. R., Kollet, S., Lehner, B., Lettenmaier, D. P., Peters-Lidard, C., Sivapalan, M., Sheffield, J., Wade, A., and Whitehead P.: Hyperresolution global land surface modeling: Meeting a grand challenge for monitoring Earth's terrestrial water, Water Resour. Res., 47, W05301, doi:10.1029/2010WR010090, 2011. 